\title{
Migration Crisis and Christian Response: From Daniel De Groody's Image of God Theological Prism in Migration Theology to a Migration Practical Theology Ministerial Approach and Operative Ecclesiology
}

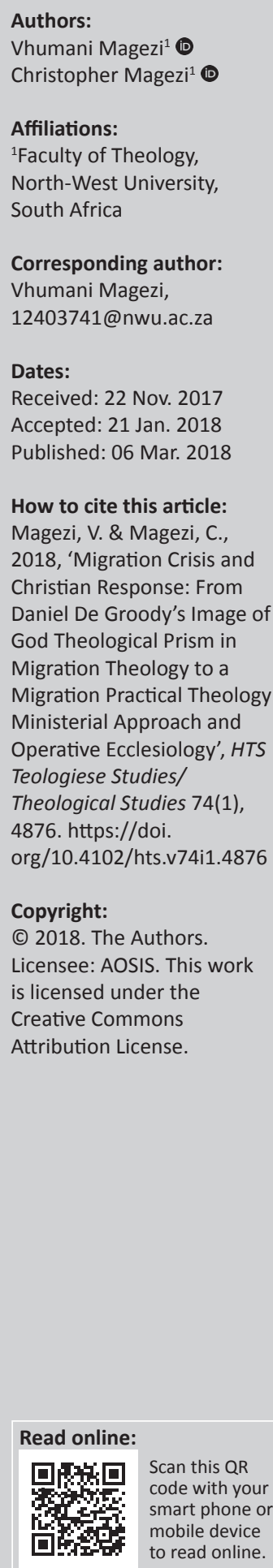

\begin{abstract}
This article identifies a need to develop an operational theology that responds to migrants in a real and constructive way. It discusses Daniel Groody's image of God prism in migration theology in order to develop an integrated understanding of the image of God. It argues that Groody's image of God prism in migration theology is assumed rather than explicit and does not proceed to inform migrant ministry design. To ensure an encompassing understanding of the notion of the image of God, an integrated understanding that integrates the various views is adopted. The adopted integrated understanding of the image of God extends beyond Groody's image of God prism in migration theology that is systematic theological and theoretical to a development of a migration diagnostic and ministry design framework that employs the various dimensions (views) of the image of God. In doing so, the integrated understanding of the image of God is employed in a practical theological conceptualisation and ministry design to promote and encourage dispositional ethics service, care, acceptance and justice. The first section problematises the challenge of theology and Christian response to migration crisis. The second section discusses Groody's image of God theological prism in migration theology. The third section discusses the various interpretations of the image of God. The fourth section proposes a diagnostic framework and ministry design that utilises the integrated image of God.
\end{abstract}

\section{Introduction}

Migration has been rising in recent years and is one of the greatest challenges that nations face (Gilmore 2016; Martin 2013; Skeldon 2013; UNHR 2015). The International Organization for Migration (2014:1) recorded that 'approximately one in seven people is migrating every day'. This rise in migration challenges the church and theology to re-evaluate its theological premises and ministerial approaches. It is important, however, as many scholars such as Schär and Groody (2009a) have noted that migration is central to church and theology. Groody (2009) noted that the theme of migration is at the heart of the Judeo-Christian scriptures. In view of the centrality of migration in theology, Magezi posed a critical question worth reflecting on: 'What practical theological approach that should be formulated to ensure effective ministry within migration situations?' (Magezi 2017:230). The above question by Magezi (2017) challenges theology and the church to develop constructive theologies that address people's real needs. A constructive theology refers to functional theology that responds to the needs of people, such as migration challenges in our time.

The challenge posed by migration crisis was aptly highlighted by the World Council of Churches (WCC), Churches Commission for Migrants in Europe (CCME) in 2015. Because of the refugee crisis in Europe, in 2015, the three General Secretaries of the WCC, CCME and Conference of European Churches ${ }^{1}$ urged their various churches and related organisations through a comprehensive letter to employ a compassionate ecumenical response to the challenges that migrants, particularly refugees, were encountering upon their arrival in Europe. However, this comprehensive letter, like other documents, lacks an underpinning theology of migration that should inform this ecumenical response (Magezi 2017:1-4). While this letter was not intended to articulate a theological position, it arguably illustrates a theological gap. In Mapping Migration, Mapping Churches Responses in Europe: Belonging, Community and Integration, Jackson and Passarelli

1.Doris Peschke the General Secretary of CCME, Rev. Dr. Guy Liagre the General Secretary of Conference of European Churches and Rev Dr. Olav Fykse Tveit the General Secretary of WCC. 
(2016:44-46) challenge churches and related organisations subscribing to the WCC to integrate foreign nationals in Europe. However, the biblical theological foundational status of their theology of migration is not developed. This approach lacks the biblical theological foundation that underlies the action.

Of the scholars engaged in migration theology, Daniel Groody is considered the leading scholar. Botha (2013:111) affirmed that in migration theology, there is none other than Groody who 'has enriched the quest for a theological missiological perspective on migration'. Certainly, one concurs with Botha's view on Groody when considering his (Groody's) innovative use of the concepts imago Dei, verbum Dei, missio Dei and visio Dei (Groody 2005; 2008; 2009a; 2009b; 2009c; 2010; 2012; 2013; 2015). All these are various doctrinal formulations that Groody brings to configure his theological responses to migration crisis. Notwithstanding Groody's useful theological formulations hinging on the notion of the image of God (imago Dei), the critical questions that emerge from his theological constructions that seem to be a black box are: What does Groody mean by the image of God, which he does not define in his theological conceptions? How could the notion of the image of God be applied in migration theology as well as in a practical theological approach to inform a design for a migration ministry? How could an integrated understanding of image of God be employed within a hermeneutics migration ministry to ensure an operative ecclesiology? In response to the above questions and the synoptic discussion above, this article considers Daniel Groody's image of God prism in migration theology and proceeds to formulate an integrated understanding of the image of God, which is then applied within a practical theological approach as well as in a diagnostic framework within hermeneutics of migrant challenges and operative ecclesiology.

\section{Problematising the notion of image of God as a theological prism}

There is an urgent need to develop a constructive and sound theology that is useful and able to address people's needs, which is termed operative theology (Magezi 2017:234). Despite the migration crisis being experienced globally, it seems many theological responses are limited in different ways. On the one hand, there are theologians who focus on reflection with little practical focus, which could be termed as systematic theological approach to migration crisis. Examples of such scholars are Campese (2012), Hilkert (1995), Groody (2008; 2009a; 2009b; 2009c; 2010; 2012; 2013; 2015), BedfordStrohm (2008), Rivera-Pagán (2012) and Aymer (2015:1). This approach sometimes lacks a rigorous interaction with the biblical text to inform a thoroughly worked out theology of migration with practical implications. On the other hand, there are scholars who suggest responses that are weak in theological theory by focusing on practical interventions with little reflection. These scholars reflect on migration from the Bible and often do not go beyond that reflection to question and test their theological formulations on the front of life challenges. The weakness with this approach is that it usually does not labour much in developing a biblical theological foundation that informs its practical response to migration.

Migration theological theory formation should entail two dimensions. On the one hand, it should develop theological categories that are theological, while on the other hand, it should be thoroughly practical to ensure that human mobility challenges are adequately addressed. Magezi (2017) and Louw (2016) maintained that human beings are homo viators, namely that they are on the move. Hence, theology and ministerial designs should be cognisant of this fact. Arguably, therefore, theological theory and migration ministry should comprise the following four elements: (1) a sound theology that constructively engages with real-life challenges; (2) the subject of migration should be considered a practical phenomenon rather than theoretical abstraction; (3) migration reflection should be informed by the notion of living life in between, that is, homo viator, people on the move (Magezi 2016:70-71, 76). Within this migration theory formation, it should be emphasised that there is no fixed theology because people's challenges are constantly shifting as people are moving. Thus, Magezi (2016) referring to migration ministry, advised that:

Care (i.e. migration care) at the in-between denotes a state of global temporariness, a flux space where people have no fixed positions. It refers to people who have moved from their familiar environments, community or country to new environments in search of happiness or better life (professional migrants) or those displaced by conflicts (refugees). This in-between therefore describes a space of confusion, anxiety, temporariness, combination of loss and gain. (pp. 70-71)

And (4) these theological categories entail fluidity, which Louw calls Zig Zagging because migration issues are fluid, multifaceted and complex (Louw 2015:14).

Noting these aspects as important conceptions that should inform migration theology and consequent responses, it is crucial to assess how leading scholars in migration theology such as Daniel Groody are approaching the subject of migration (Olsen 2015). Groody is a leading scholar in migration theology and an award-winning author and film producer, who is currently teaching theology at the University of Notre Dame, where he serves as the Director of the Centre for Latino Spirituality and Culture at the Institute for Latino Studies (ibid). As indicated in the preceding discussion, Botha (2013:111) considers Groody as a leading scholar in migration theology, particularly his innovative use of the notion of the image of God. Groody innovatively delineated four foundations of this theology: the imago Dei, crossing the problem-person divide; the verbum Dei, crossing the divinehuman divide; the missio Dei, crossing the human-human divide; and the visio Dei, crossing the country-Kingdom divide (Groody 2005; 2008; 2009a; 2009b; 2009c; 2010; 2012; $2013 ; 2015)$. Groody brings various formulations to configure his theological responses to migration crisis. Magezi (2017:5) noted Groody as employing many doctrinal theological formulations such as the interconnection between the 
doctrines of incarnation and reconciliation, which destroys the dividing walls between God and humanity, and humanity and humanity (Magezi 2017:5). In Magezi's (2017:5) view, Groody views the twin doctrines of the incarnation and reconciliation as the central basis for Christians' acceptance of migrants or foreigners'. Groody (2009a:652) views the doctrines of incarnation and reconciliation as providing humankind with the notion that the eternal God in Christ came into a foreign territory of estranged humanity as a means of redefining the 'borders between neighbours and opens up the possibility for new relationships'.

Further to his systematic theological approach to migration crisis embedded in his formulations, Groody ${ }^{2}$ (2009a:642) brought the aspect of human beings as the bearers of the image of God to challenge human beings to abandon all political labels that are placed on migrants. These labels contribute to the discrimination of migrants by migrants' hosting nations. While Groody usefully brought the doctrine of the image of God to operate as his basis for the hosting nations and their local communities to view migrants positively, he doesn't establish the biblical theological foundational status of the doctrine of human beings as the bearers of the image of God. It seems Groody is unaware, disregards or doesn't significantly interact with other biblical theologians such as Atkinson (1990:36), Calvin (1965:93) and Arnold (2009:44) who argue that the meaning of human beings as created in the image or likeness of $\mathrm{God}^{3}$ has been hugely debated in the academic domain because scholars have significant differences on the subject. In his survey of the history of interpretation of the imago Dei (in Gen 1:26-27) from Philo to the present, Simango (2016:172-190) attests to the various interpretations that have caused huge debate in this proposed subject. Sadly, Groody doesn't explain what he means by the image of God. He seems to proceed from an assumed position that people share a common understanding, which is incorrect. Therefore, it is critical to understand the meaning of the image of God in human beings in order to bring this understanding to bear on migration theological formulations and Christian migration response. Arnold (2009:44) maintains that it is important to examine the concept of the image of God (imago Dei) because although the Bible speaks of human beings as created in the 'image' or 'likeness' of God, there is no single understanding and interpretation of the image of God. Scholars explore the concept of the creation of humankind in the image of God from physical; spiritual, moral and rational; relational; and functional perspectives (Simango 2016:172-190; Atkinson 1990:36). Emerging from this observation, therefore, is the question: what is the integrated view of human beings as bearers of the image of God that should result in creating and challenging people to develop dispositional ethics of care to

2.Rivera-Pagan (2012:586) and Zetter (1991:40) are some of the scholars who propose that the image of God should be the primary interpretation of human beings.

3.I am aware that Atkinson (1990:36), Calvin (1965:93), Dillman (1897:80) and Arnold (2009:44) indicate that many scholars question if the words image or likeness means the same thing. As our discussion is not focusing on the differences of these means the same thing. As our discussion is not focusing on the differences of thes terms, one should consult Atkinson (1990.36), Calvin (1965:93) and Arnold (2009:44) for clarification in this matter. For example, Calvin (1965:93), Arnold (2009:44), Dilman (1897:80) and Atkinson (1990:36) consider the terms 'image' and 'likeness' as synonymous words in Genesis 1:26-27. In this thesis, will take these words to mean the same as these scholars have done. migrants? How could this integrated understanding cause dispositional ethics of care for other people such as migrants to ensure accommodative and embracing response? What is Groody's understanding of the image of God that should be examined to clarify the notion of the image of God?

\section{Daniel Groody's image of God prism in migration theology}

Groody (2009a:642) argues that the primary interpretation of migrants as the image bearers of God is one of the dominant views that should be considered in substantial detail. In agreement with Zetter (1991:40), Groody (2009a:642) posits that the political labels which are placed on migrants by the host nations contribute towards discrimination by the local communities. In response to the language problem as one of the causes for the discrimination against migrants, Groody (2009a:642) brings the doctrine of creation to bear on the matter. He claims that human beings are created in the image of God (imago Dei) (cf. Gn 1:26-27, 5:1-3, 9:6; 1 Cor 11:7; Ja 3:9). Thus, this should be our primary basis in perceiving migrants (Groody 2009a:642; Hilkert 1995:190-204). In saying this, he urges hosting nations to perceive migrants as, first and foremost, people created in the image of God. This is a central doctrine which emerges from the early pages of scripture. The interpretation of migrants by their political status or categories (such as legal, illegal, undocumented and alien) is a complete denial of the migrants' identity which is rooted in the image of God (Groody 2009a:642). Even though Zetter (1991:40) wrote before Groody, he concurs with him in his affirmation that 'far from clarifying an identity, the label conveys, instead, an extremely complex set of values, and judgments which are more than just definitional'. Here, the problem is that perceiving migrants in political terms will make them susceptible and, therefore, exposes them to exploitations by the local communities and employers of the hosting nations (Magezi 2017:6).

In other words, Groody (2009a; cf. Magezi 2017:6) is of the opinion that the perception of migrants as primarily 'lawbreakers, aliens or criminals' is dangerous because it will make the sufferings of migrants have no claim to the hosting nations or local communities. In this way, the hosting nations can be content on their side of the dividing wall because they convince themselves that the migrants are 'excluded for a reason' (Groody 2009a; Magezi 2017:6). This treatment will definitely expose migrants to an inescapable 'psychological colonisation' that they have to live with in their new homeland (Groody 2009a:642; cf. Magezi 2017:6). In signifying this, Groody hopes that if the local communities and the authorities of the hosting nations perceive migrants as people created in the image of God, they are going to treat migrants with their God-given identity. This understanding will shape the migration debate, particularly the international formulation of migration policies, in a positive way (Groody 2009a:644; cf. Magezi 2017:6). In this way, Groody is reinforcing the doctrine of the imago Dei as the primary principle that should function as the hosting nations' (local communities) primary interpretation of migrants. The use of the imago Dei as the 
primary principle in perceiving migrants is crucial in making the native communities of the hosting nations to cease their exploitation and racial discrimination of migrants (Magezi 2017:6). This is because the local communities of the hosting nations will primarily perceive migrants as important people of equal status (whose identity and dignity is rooted in God) with themselves before God (ibid).

However, the biblical theological foundational status of Groody's image of God prism in migration theology is not thoroughly defined, which leaves us with a question of what he refers to by the meaning of the image of God. That is, one is not aware of what Groody means by human beings as the bearers of the image of God. As well, one is not cognisant of the various theological tenets that Groody uses to configure his doctrine of the image of God that he brings to bear as a response to migration crisis. The challenge in Groody's image of God's prism in migration theology is amplified when one identifies that there are various interpretations regarding the aspect of human beings as the bearers of the image of God (Arnold 2009:44; Atkinson 1990:36; Calvin 1965:93; Simango 2016:172-190). Many scholars explore the concept of the creation of humankind in the image of God from the following perspectives: physical; spiritual, moral and rational; relational; and functional perspectives (Atkinson 1990:36; Simango 2016:172-190). Given these various views in regards to the concept of human beings as the bearers of the image of God, the next section discusses these views from a biblicaltheological perspective to examine their validity. This is done with the aim to configure an integrated approach of the notion of the image of God that leads to dispositional ethics of care to one another resulting in responsibility towards migrants.

\section{Interpretations of human beings as the bearers of the image of God} A physical view of the image of God

Atkinson (1990:36) argues that scholars who understand the image of God in a very physical sense avow that God looks exactly like human beings in his physical appearance. They understand that the infinite, eternal, transcendent God can look identical with human beings if he steps down into the constrained space of this world (Atkinson 1990:36). This position is substantiated by pointing out the existing uniqueness between humankind and other animals of the earth (Atkinson 1990:36). This view can be rational because God, in and through Christ in the incarnation, has once and for all moved into the bounds of space and time in order to identify with all humankind for the sake of our redemption (Torrance 1996:18). In the incarnation, God did not assume the form of other earthly creatures besides that of the humankind that he created in his image. However, this view seems unconvincing from scripture because God is Spirit (cf. John 4:24), so the incorporeal nature of God as elucidated in Scripture does not warrant the physical aspect of the image of God (De La Torre 2011:21-22). The incorporeal being of God is affirmed in 1 John 4:12 when the apostle affirms that no one has ever seen God, besides Jesus Christ who eternally co-exists with God the Father (Jn 1:18; 3:13). In this way, one cannot use the incarnation to affirm the physical aspect of the image of God because it is inconsistent with the incorporeal nature of God. De La Torre (2011) encapsulates the foregoing understanding in the following way:

To be created in the likeness of God refers to more than just the corporeal, especially since God as spirit has no legs, arms, feet, and so on. Humans are metaphorically like God spiritually, mentally, emotionally, and physiologically. If we want to understand something about the reality of God, then it behooves us to look toward humans, who are the image or copy of the original. (pp. 21-22)

De La Torre's conception of human being as the bearers of the image of God is important because it demonstrates that human beings are not like God in physical sense because God is an incorporeal being who cannot be divided, separated or portioned. This means that although people are created in the image of God, it follows that there is a robust distinction between humankind and God. In this way, we can think of the image of God as something beyond the physical sense. This leads us to the next set of interpretations that view the image of God as connoting something beyond the physical sense.

\section{The moral, rational and spiritual view of the image of God}

The conception of the image of God in Genesis 1:26-27 as referring to the moral, rational and spiritual nature of humanity is closely associated with each other because these natures speak of the image of God as something within humankind, instead of something outside of them (Atkinson 1990:40; cf. Dillman 1897:80-83). In view of the image of God as referring to the spiritual aspect of humankind, Calvin (1965:94) and Skinner (1930:32) concur with De La Torre. Calvin argues that the New Testament expounds the meaning of the image of God than the Old Testament. The Old Testament simply tells us that human beings were created in the image of God and that that image was destroyed by the fall in Genesis 3. Thus, in order to underscore the meaning of the image of God, Calvin (1965:94) commenced from the New Testament and moved back to the Old Testament because he asserts that we 'judge from its restoration what it originally had been' before the fall in Genesis narrative. In this way, one can argue that Calvin is bringing to the fore the foundational status of the doctrine of creation, the fall and redemption to bear in our interpretation of human beings as the bearers of the image of God. Calvin understands that human beings were created in the perfect image of God in Genesis 1:26-27; however, the fall in Genesis 3 marred that image (Calvin 1965:94). However, through Jesus Christ (the very God himself), the perfect image of God in man that was marred by the fall is being reordered, renewed and reconstructed for those who are saved by the gracious God through faith in Jesus Christ.

Colossians 3:10 and Ephesians 5:23 are the central passages that Calvin (1965:94) employs to assert that Christians are being renewed into the image of God. Because Calvin 
understands that the contexts of these passages are spiritual regeneration, he reinforces that 'spiritual regeneration' in Paul's mind is nothing less than the restoration of the image of God to humankind (Calvin 1965:94). In Calvin's view, it is spiritual regeneration because the centre of the divine image of humankind was intrinsic in 'the mind and heart of Adam'. Unfortunately, Calvin does not explain what he means by spiritual personalities or attributes of man that were lost at the fall and now renewed for those who are in Christ. What we understand from Calvin is that all human beings are created in the image of God, but that image was distorted by the fall. However, Christ as the very God himself assumed our human mode of existence in the incarnation in order to redeem the marred image of God by the fall in Genesis 3. This means that on the one hand, the image of God in nonChristians is not yet renewed because they are outside of Christ. On the other hand, God the creator who came to recreate the distorted image of God in humanity means Christians' image of God has been renewed by their union with Christ through faith. Having said that, we are of the view that the spiritual aspect of the image of God for Christians is not yet perfect because Paul speaks about it as an ongoing process for those who are united with Christ by faith (Col 3:10; Eph 5:23).

In regards to the moral view of the image of God, scholars who hold this position argue that human beings are given the moral capacity to relate and to love one another (Atkinson 1990:36). Here, God has created human beings with the ability to enter into relationship with one another and to love one another (De La Torre 2011:24). That is, human beings were fashioned to portray the character or attributes of God who has love as the essence of his being in the ontological trinity (1 Jn 4:8; 4:16) and economy of salvation (Jn 3:16; De La Torre 2011:24). Just like the spiritual aspect of the image of God, the moral aspect of the image of God in humankind was distorted by sin, so human beings are not able to model the moral aspect of God such as love for one another. However, Christ renewed the moral aspect of the image of God for those who are in Christ so that they are able to exhibit their love for God and fellow human beings as the bearers of the image of God. The moral attributes of human beings that God shared with all humankind as his image bearers are demonstrated by Christ as an ideal man in the image of God whom all humankind have to emulate both behaviourally and ethically. That is, for Christians, the moral aspect of the image of God is renewed by their union with Christ through faith; however, it is continuously nurtured into Christlikeness as we await the consummation period. For nonChristians, the moral aspect of the image of God is not renewed because they are not united with Christ by faith. Thus, the moral conduct of humanity has to be governed by these moral attributes which are rooted in the being of God as God has demonstrated it for us in and through Christ in the incarnation, and consequently his earthly life. In applying the moral aspect of the image of God to both Christians and non-Christians, we observe together with De La Torre (2011) that:
The diversity of creation as expressed in humanity, it is presumed, becomes an act of divine love, a love that seeks companionship, a love that exists for others. Being human can never occur in isolation, apart or disconnected from others. (p. 24)

In view of the restored moral image of God in Christ for mankind, we argue that Jesus Christ:

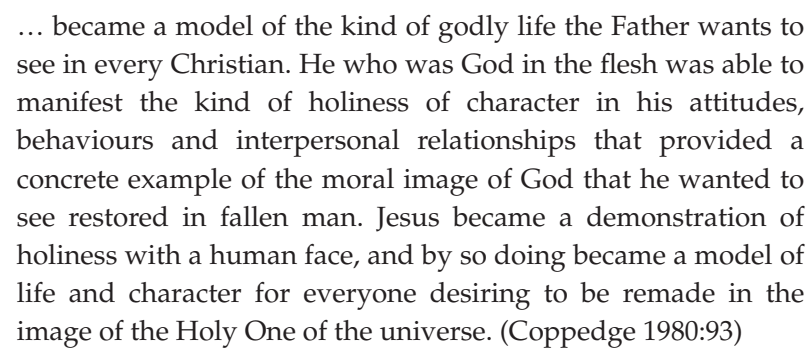

Furthermore, other scholars have referred to the selfawareness or self-conscious (rational) that is intrinsic within humankind as another aspect in interpreting humankind as the bearers of the image of God (Atkinson 1990:37; Keil \& Delitzsch 1978:63). These scholars argue that God is selfconscious and he has granted humanity the capacity of selfconsciousness (rationality) so that they can operate or function as the bearers of his (God) image in the world (Atkinson 1990:37). In conclusion, De La Torre (2011) articulated well the spiritual, moral and rational aspects of the image of God in his prolonged argument that:

Unlike the rest of creation, these humans exist in relationship to God, to creation and to one another. It is these reciprocal relations that define humans, as such relationships provide opportunities for self-realization. To be in right relationship is to be in right relationship with creation and other people. To be human in the image of God is to be also for others. If God is love, whose very essence expresses concern for others, then to be created in the image of God means that humans are product of love expressed as being for others ... Being for others becomes possible as we become conscious of others. But when we cut ourselves off from the vast majority of humanity, which happens to be marginalized and disenfranchised, refusing to hear their cry or see their condition, we cease being for others. (p. 24)

\section{The relational view of the image of God}

The relational view of man as created in the image of God refers to humanity as the counterpart of God that can have relationship and history with God (Atkinson 1990:37). In the creation narrative of Genesis 1, God created human beings and has placed them in vertical and horizontal relationship (Barth 1960a:184-185; cf. Westermann 1987:157-158). On one hand, the vertical relationship refers to human beings' special relationship with God, and on the other hand, the horizontal relationship connotes human beings' relationship with one another. In Barth's (1960a:184) view, the relational aspect of the image of God is evident in the fact that all humankind, both man and woman are the bearers of the image of God. Human beings have the capacity and ability to have a relationship with both God and one another. This notion is interlinked with Barth's (1960b:203) assertion that God created man to be in eternal relationship with himself and 
with one another. However, the relationship between humankind and God is significant because it is a relationship that God did not venture with any another earthly creatures (Atkinson 1990:37). Likewise, Westermann (1987:157) notes that human beings are capable of interacting and listening to God, something that other earthly creatures do not poses in their being. In agreement with Barth and Westermann, we argue that the relationship between man and God is one of the central messages of Genesis 1:26-27. Given this, the image of God in man should be primarily understood as the 'particular relationship in which God places himself with human beings, a relationship in which we become God's counterpart, his representative and his glory on the earth' (Atkinson 1990:37).

However, the vertical and horizontal relationship was affected by the fall in Genesis 3. Thus, in contextualising this notion to our Christian faith, Atkinson (1990:37) bound the doctrines of creation, the fall and salvation together as he employs 1 Corinthians 3:18 to underscore that Christians are being renewed into Christ-likeness (1 Cor 3:18). In this case, it is through Christ, the very God himself that humanity can be restored back to their perfect relationship with God and with one another. Atkinson (1990:37) explores this view in the New Testament by establishing Jesus Christ as the only human being who is the visible image of the invisible God (Col 1:15); thus, one can only see the exact image of God in Jesus Christ (ibid). The New Testament speaks of Christians as being transformed into the likeness of Christ (2 Cor 3:18) so that they can be in a perfect relationship that was reflected by Christ to us in his earthly ministry (Atkinson 1990:37).

That is, the New Testament makes it clear that if we desire to see the true image of God, we see it in Jesus Christ's relationship with God the Father, namely, the relationship of the Son to the Father (Atkinson 1990:37). Barth (1960b:41) corresponds with the aforementioned assertion when he notes that Jesus is of one being with God the Father; thus, in his incarnational mystery and earthly life, Jesus operates as the source of our knowledge of true humanity that was created by God before the fall. However, in interlinking the fall and redemption to the relational view of the image of God, Atkinson (1990) correctly advances that:

Jesus is the image of God in this world because he is in a relationship of loving communion with his Father. And we reflect God's image to the extent that we are growing to the personal communion with him, and therefore with one another. (p. 38)

\section{Functional view}

A considerable number of scholars (Arnold 2009:44-45; Clines 1968:87-88; 1993:426-428; De La Torre 2011:25; Hart 1995:317-319; Middleton 1994:8; Moltmann 1991:220-221) have understood the image of God in Genesis 1:26-27 to be denoting human beings as the visible representatives of the

4.It seems Barth (1960a:200) does not necessarily underscore that sin did not obscure the image of God; instead, it has concealed the true human nature from all humankind, and this has affected our relationship with God, as well as with one another. invisible God (the creator) in subduing the earth. That is, although these scholars come from different angles in establishing this position, it is apparent that they linked the image of God with Genesis 1:28 that charges human beings to procreate and subdue the earth as referring to human beings as the bearers of the image of God (Arnold 2009:44-45; De La Torre 2011:25; Moltmann 1991:220). In view of procreation, Atkinson is of the opinion that both male and female humankind were created as the bearers of the image of God (Gen 1:26-27) and were immediately granted with the blessing of fruitfulness and subduing the earth by God (Gen 1:28). Thus, the uniqueness of mankind to other creation is in procreation and dominance over the whole earth (Arnold 2009:44; Atkinson 1990:41). It is important, therefore, to note that the aspect of procreation is less convincing because animals and even trees procreate as well. Although, the view of procreation as one of the interpretations of the image of God in man can be possibly valid because God is the creator so to create for human beings is to be like God. It is apparent that scholars seem not to identify the weakness of procreation as one of the interpretations of the image of God in man. Instead, they simply link these two unique aspects of humankind as the meaning of human beings as the bearers of God's image. For example, Atkinson (1990) argues that:

Human creativity, and especially human procreativity, is part of the outworking in our histories of the creative love of God in us as his image. Human creativity thus expresses something of the nature of God's creativity, and as Genesis 1:28 makes clear, this is not only found in the fruitful and multiplying, but in subduing the earth and having dominion over it. (p. 41)

At this point, we can strongly concur with Moltmann (1991:220) that to be created in the likeness of God is none other than perceiving human beings as God's representative in the world because it confronts us with predominant distinction between humanity and all other animals in the animal world. Human beings are at the centre of God's creation. Although the term 'image' or 'likeness' of God can be understood as an anthropological phrase, we agree with Moltmann (1991:220) that the term should be understood first and foremost as a theological term. However, once this is established, the question to be answered is the following: in what ways are human beings serving as the representatives of God in the world? In responding to this question, Moltmann (1991) rightfully affirms that:

As God's image and appearance on earth, human beings are involved in the fundamental relationships: they rule over other earthly creatures as God's representatives and in his name, they are God's counterpart on earth, the counterpart to whom he wants to talk, and who is intended to respond to him, and they are the appearance of God's splendour, and his glory on earth. (pp. 220-221)

In agreement with Moltmann, Arnold (2009:44-45) establishes the image of God as referring to the dominion of humanity over the world by comparing Near Eastern materials (Egypt and Mesopotamia) with the history of ancient Israel. On the basis of the similarities that historians have discovered from Egypt and Mesopotamia, the term image of God is 
closely associated to 'royal language', which presents Pharaoh, the king of Egypt as the 'image of (a) god' (Arnold 2009:45). Although the danger of the aforementioned comparison is placing responsibility of subduing the earth to only individuals who are in ruling positions, Arnold argues that the Bible view is that all human beings are created to function as the bearers of the image of God by exercising their dominion and rule over the earth as the agents of God. That is, the importance of the human species is not confined to a particular group of people because every human being is in the image of God; therefore, all humankind are tasked by God to exercise dominion and rule over the world as his (God's) agents. In speaking about the supreme importance of every human being over all other created creatures by God, Arnold (2009) helpfully advances that:

\footnotetext{
... This creature (human being) is unlike others, and is intended to rule and have dominion over the whole. It is therefore appropriate that God, the sovereign creator of the universe, has in a sense replicated himself in creating this unique creature, the human. (p. 45)
}

However, De La Torre (2011:25) is aware of the challenge of understanding the image of God as inherent in our exercising of dominion and rule over the world because of the fall in Genesis 3..$^{5}$ In acknowledging the distorted functional aspect of the image of God in man, De La Torre understands that our current human structures in our societies (i.e. judicial, government, economic, political, etc.) apparently do not allow everyone to be in a position of influence (Arnold 2009:45; De La Torres 2011:25). There is a tendency for those who are in positions of influence in various spheres of human society to forget that they are part and parcel of God's creation. This is because the human understanding of having dominion and rule over the word is corrupted by sin to the extent that those who are in power have a tendency of misunderstanding 'to rule' as to place themselves 'over and above' creation, and consequently overlook that they are to rule for the well-being of the creation that includes other humans (De La Torre 2011:25). In De La Torre's (2011:25) view, if one does not rule for the interest of all God's creation, he is definitely destroying the creation that God had contracted them to rule in love as his (God's) divine agent. In order to exercise our rule and dominion over the earth as just and faithful stewards of God's creation, De La Torre (2011:25) reinforces that one 'requires seeking harmony not only with creation but with one another. To disproportionately extract more of the earth's resources to the detriment of others who are more vulnerable' is against God's design of creation. De La Torre's affirmation is supported by Atkinson (1990) when he diminishes the entire notion that equates dominion with exploitation. Atkinson (1990) argues that:

5. Kidner (1967:52; cf. De La Torre 2011:21-25) argues that Genesis 1:26-28 have been used to justify 'patriarch and oppressive structures'. He is against people who refe to God in masculine terms as he or she since this is 'reducing God to a controllable to God in masculine terms as he or she since this is 'reducing God to a controllable concept' that serve as an instrument to injustice or oppression. Both men and women are created in the image of God without any exception. In his view, 'by gendering God we participate in blasphemy. If both male and female are made in the image of God, then the worthy and dignity of all humans are affirmed (Kidner 1967.24). The New Testament doctrine of 'sexes spiritual equality' in Galatians 3:28, 1 Peter 3:7b (heirs together) is depicted by Kidner as against calling God in sexist languages.
Dominion cannot be exploitation, but must be seen in the sort of facilitating servanthood which maintains an environment in which persons who reflect something of the nature of God's love and creativity can be at home. (p. 41)

Having considered the various interpretations of the image of God, the question that arises is: what is the understanding of the image of God that integrates these various views? In what ways does this understanding clarify the notion of the image of God, which is assumed in Groody's conceptions? How could this integrated understanding be applied to diagnose attitudes towards migrants as well as inform a practical theological approach and a ministerial design?

\section{A diagnostic framework and ministry design that utilises the integrated understanding of the notion of image of God within a practical theological approach}

\section{A link between practical theology and operative ecclesiology}

The challenge of developing ministerial approaches that respond to the public issues like migration is a practical theology and ecclesiological challenge. It is a challenge to develop an operative ecclesiology (Magezi 2017:234). An operative ecclesiology entails engaging pressing public issues within concrete situations of people rather than abstractions. This means the Bible and dogmas are brought to bear on communal life systems. Practical theology and operative ecclesiology are clearly intertwined theological endeavours. Polak (2014:1-2) rightly asserted that practical theological reflection should start with the contexts of people, for example, the current migration crisis. Practical theology is a theological approach where theory and practice cooperate (Anderson 2001; Dingemans 1996; Hendriks 2004; Louw 1998; Osmer 2008). Practical theology, as Hendriks (2007:1002) maintains, is doing theology and being church in a manner that people's contexts influence theological formulations and institutional designs. Hendriks (2007:1002) added that this means theology and ecclesiology should focus on a contextual praxis, that is, on a reflective engagement of faith communities in the world. Osmer (2008:11) proposed an important practical theological approach with four core tasks of practical theology, which are: a descriptive-empirical task (What is going on?), an interpretive task (Why is it going on?), a normative task (What ought to be going on?) and a pragmatic task (How might we respond?). With particular relevance to operative ecclesiology, the pragmatic task seeks to provide guidance and transforming assistance for church leadership and congregants to respond to practical challenges, such as migration.

Fowler (1983) aptly captured practical theology as practical knowing. That is:

a knowing in which skill and understanding cooperate; a knowing in which experience and critical reflection work in 
concert; a knowing in which disciplined improvisation against a backdrop of reflective wisdom, marks the virtuosity of the competent practitioner. (pp. 154-155)

Thus, practical theology is about utilising the Christian knowledge to shape and inform practical life. It entails continuous imagination of what it means to live a whole life in the world. Cahalan and Mikoski (2014) maintain that practical theology is about experience. This human experience is not limited only to ideas and the life of the mind but involves other features. These features include imagination (Cahalan \& Mikoski 2014:3). Magezi and Magezi (2016:6) argue that imagination involves an array of things such as interpretation, reflection and even dreaming of alternative ideal situations in a broken world. As theology explores an imaginative operative ecclesiology, theory and action merge in ministerial design. This way, Louw (2014:35) rightly argues, practical theology will entail fides quaerens intellectum [relational reflection and theory formation] and at the same time fides quaerens actum [action and transformation]. Thus, practical theology should lead to strategic development of models of doing innovative practical ecclesiology (operative ecclesiology).

Migration crisis as a practical phenomenon calls for a theological theory that practically engages with the challenges experienced by host country communities and migrants themselves. The displaced migrants are living at the in between of their country and unfamiliar environments. Practical ecclesiology should thus be fluid to incorporate and address complex dynamics that arise from migration. To address these challenges within a practical theological approach, theory formation and practical hermeneutics that is informed by an integrated notion of image of God provides a useful framework.

\section{Integrated understanding of the image of God and its implications}

The image of God assigns humanity as the supreme created creature by the creator (God). God created human beings in his likeness and has placed them in a particular relationship and fellowship with himself (God), as well as with one another (human to human relationship and fellowship). The God-man relationship is the relationship that God did not venture with any other creaturely existence besides human beings. As Berkouwer (1962:34-35) notes, human beings are unique from the entire created creatures by God because they are able to relate to God, as well as to one another. Furthermore, human beings were created with moral, rational and spiritual attributes that grant them the capacity to love God and one another, as well as to be self-conscious like God.

As the bearers of the image of God, human beings also stand as the representative of God in the world in exercising dominion and rule over the entire creation. This dominion and rule they have to exercise over the world is servanthood dominion as the agents of God. This disqualifies any notion of exploitation of other humans, as well as advancing the necessity for those in position to rule for the best interest of all human beings made in the image of God. However, many scholars who subscribe to these various positions concur that the image of God in humankind was affected by sin in Genesis 3. However, with Jesus Christ, the creator in action, the image of God in human beings is renewed for those who are united with him by faith. This renewal has to be understood in view of the consummation in which God in Christ would make everything perfect.

Now, the fact that the image of God refers to the physical aspect of human beings is problematic because of the incorporeal nature of God. Thus, after excluding the physical aspect of the image of God in humankind, we bring together all other various interpretations of the image of God discussed above to construct the need to view all human beings from God's perspective because they are the embodiment of God's image in many and different ways. In view of migration issue, all human beings are equal before God as his representative image and glory in the world. Therefore, they are to be loved and treated justly in all spheres of society. As well, the fact that all human beings are the bearers of the image of God implies that God treats people equally, and this should be the motif for universal humanity's love and care despite tribal, language, ethnic and national boundaries. Thus, regardless of whether someone possesses an influential position or not, the doctrine of human beings as the bearers of God's image should challenge people to embody dispositional ethics of care to other human beings as well as help each other. This entails responsibility towards other human beings.

Furthermore, the aspect of human beings as the bearers of God's image should challenge nationals of migrants' hosting nations to perceive foreign nationals as people of equal status that they are to love like their fellow nationals and family members. This is to say, people should first and foremost be considered as equal to each other before one moves to strike the distinction of whether one is a foreigner or national within hosting nations. This primary perception of humanity will consequently cause all people to act in a responsible way towards universal humanity irrespective of their colour, race, culture, language, ethnic background. In other words, the concept of all humankind as the bearers of the image of God implies that people should treat each other equally as the bearers of the image of God regardless of their religious, cultural, ethnic, tribal, national and language background. This is why Ng'ang'a (2010:iii), Groody (2009a:642) and Botha (2013:109-113) affirm that the aspect of all human beings as the bearers of the image of God is critical for bringing fundamental change to the relationship between migrants and the local people.

Indeed, this challenges local communities to have complete solidarity with many marginalised and discriminated migrants in their nations, and consequently, this solidarity 
will compel them to address the challenges of their fellow human beings (Olsen 2015). Emerging from the solidarity of local people with migrants is the local community's recognition of the dignity of migrants, particularly refugees at their doorsteps (ibid). International migrants, particularly refugees, have left everything they have in their countries of origin for safety and in search of better lives in a new homeland (Magezi 2016; Olsen 2015). Given this, if local communities act accommodatively towards migrants, this will result in a deep sense of peace to migrants who are always in fear of separation, discrimination, exploitation and abuse by the native people. If migrants' hosting communities fail to live responsibly to their fellow human beings, particularly migrants, it follows that they are failing to care and love their fellow human beings in a manner that God desired to see acted upon all his image bearers.

\section{Towards a diagnostic framework and ministry design that utilises an integrated notion of the image of God}

Louw $(1998 ; 2016)$ argued that a diagnostic framework is not about caging issues in fixed categories but rather about a hermeneutical understanding of life issues. It shows the links and interconnections, which provide insight into the systemic networking of attitudes and paradigms. This helps individuals to consider different strategic options, especially when one has to link the options to basic theological categories. Louw (2016) maintained that a diagnostic chart helps one to see the bigger picture, the networking dynamics of life as an existential and qualitative category. Within this framework, life is a web where the dynamics and structural interplay between various situations, experiences and relationships should be understood as part of a practical reality in life.

Drawing from the preceding discussion on the meaning of human beings as the bearers of the image of God, three views (i.e. spiritual, moral and rational; relational; and functional) have been embraced in an integrated manner while image of God as referring to the physical aspects has been discounted because of its problematic nature owing to the incorporeal nature of God. The integrated understanding of the image of God has been applied in a diagnostic framework and design of a migrant ministry (Figure 1).

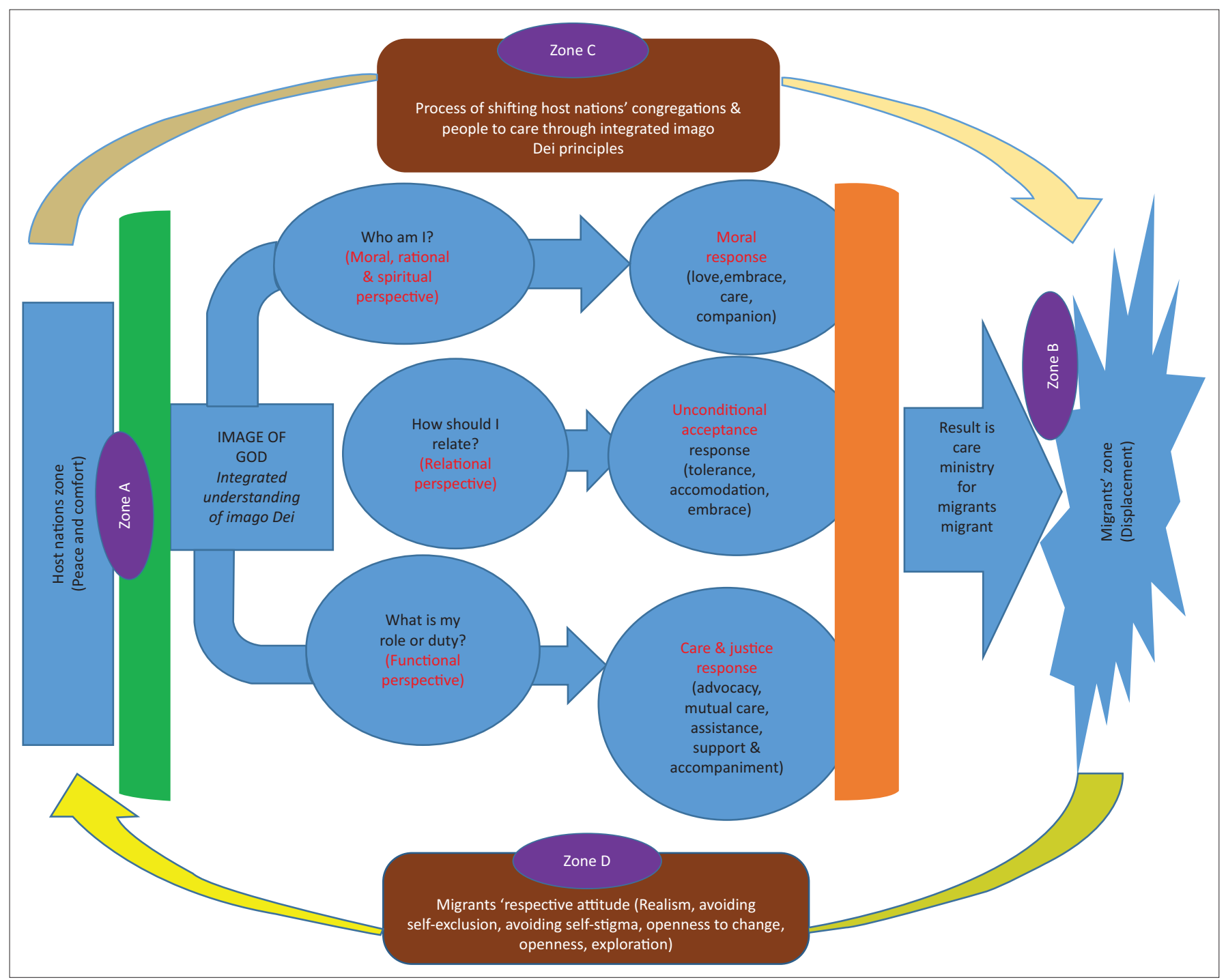

FIGURE 1: Diagnostic framework and design for migrant ministry using integrated understanding of image of God. 
Figure 1 indicates the various interpretations of human beings as the bearers of the image of God. Although scholars differ in their views on the image of God, we view each interpretation as contributing a dimension about the image of God that cannot be offered by other approaches. Therefore, we are proposing an integrated complementary view of these various interpretations of the image of God.

Within the above diagnostic framework, Zone A represents a position of host country churches and communities. It describes their situation of peace, security, stability and other comforts. Zone B represents the position of migrants as displaced people. They are gripped with issues such as fear, uncertainty, anxiety, trauma and having physical needs. Zone $\mathrm{C}$ describes the process of shifting host nations' communities and congregations to develop responsive migrant ministries of care using an integrated understanding of the image of God. It (Zone C) indicates how each understanding of the image of God could be employed to evaluate congregations and communities regarding their disposition towards migrants and consequently challenge them to shift towards accommodating and care for migrants.

For Christians, the moral, rational and spiritual perspective describes their transformed state of being through Christ to be true bearers of God's image. However, the understanding of image of God extends to include non-Christians as well. God's general revelation indicates diversity in God's creation (i.e. humanity in our case), which shows God's divine love to all humanity. Love is a universal principle that should guide our response to other human beings. A rational understanding makes human beings to be self-aware and self-conscious of their position and situation. Thus, the moral, rational and spiritual understanding of the image of God can be invoked for a congregational and community diagnostic analysis by asking the questions 'Who am I as an individual? Who are we as a congregation or community?' In responding to these questions, the principle of love challenges human beings to embrace others (i.e. in our case migrants) unconditionally. As rational human beings, it means we should self-reflect on our privileges and advantages in order to help other human beings. The renewed state (being) of Christians challenges congregations to be sensitive to other human beings who are God's image bearers while the principle of love binds all humanity. Thus, by asking 'who am I or who are we', the moral, rational and spiritual perspective assists in congregational analysis. This analysis results in moral responses of love, embrace, care and companionship of other human beings (migrants).

The relational perspective of the image of God means human beings have capacity and ability to have a relationship with God and with one another (Barth 1960a:184). Only human beings have the capacity to form these relationships. This indicates that human beings are relational beings. Relationship implies partnership and companionship. In employing the relational perspective in diagnosis, the congregation or community asks the question 'How should I relate?' A response to this question entails unconditional acceptance to other human beings (migrants in our case).
This acceptance is evident through tolerance, accommodation and embrace. Congregational ministries to migrants such as practical community assistance, family enrichment, church and community diversity and integration activities, cultural activities, etc., will serve towards building relationship building between host country people and migrants.

The functional perspective states that human beings are created to function as bearers of the image of God by exercising dominion and rule the earth as agents of God. However, this care and dominion is not confined to one group of people (e.g. host country people) because all human beings are the same (including migrants). Thus, human beings who are trusted to lead should exercise that leadership over other God's creation (human beings) in a way that reinforces harmony. Within a diagnostic framework, the following question is asked: 'What is my role or duty?' This question challenges host nation communities to reflect on their privileged position over migrants, which challenges them to take responsibility over the migrants. This results in care and justice. The congregational activities such as migrants' advocacy, practical mutual (koinonia) care ministries and practical assistance to physical needs support in settling in a new environment and accompaniment.

While Zone $\mathrm{C}$ indicates processes aimed to shift negative and apathetic attitude of host country communities to promote practical care for migrants, Zone D indicates a position of migrants that needs to be determined and be equally shifted. When migrants enter host countries, they need to understand the dynamics at play. These dynamics include language barrier, access barrier to various services, etc. Migrants therefore need to be realistic about their situation and moderate expectations (realism), avoid self-stigma and selfexclusion. They need to be open to new learning and be able to explore new things. Zone D therefore is challenge for migrants to adopt attitude change as well to complement initiatives by host nations.

\section{Conclusion}

This article has discussed Daniel Groody's image of God prism in migration theology in order to establish an alternative option for a constructive theology. It is argued that Groody's image of God prism in migration theology is not thoroughly worked out. That is, the biblical theological foundational status of Groody's image of God prism in migration theology is not clearly defined, which leaves one with a question regarding what Groody means by the creation of human beings in the image of God. As well, one is not cognisant of the various theological tenets that Groody uses to configure his doctrine of human beings as the bearers of the image of God that he applies to migration challenges. This challenge in Groody's image of God prism in migration theology is amplified when one identifies that there are various interpretations regarding the aspect of human beings as the bearers of the image of God. Many scholars explore the concept of the creation of humankind in the image of God in different aspects such as physical; spiritual, moral and 
rational; relational; and functional perspectives. In view of the aforementioned various interpretations of the image of God in human beings, the article has presented all these various interpretations and considered an alternative position that combines all other views of the image of God in humanity, excluding the physical view.

Emerging from the combined views of the image of God in humankind was the need for local communities to have complete solidarity with many marginalised and discriminated migrants in their nations. In acting responsibly towards migrants, the migrants' hosting nations and their respective local communities will be recognising the dignity of migrants, particularly refugees who they see at their doorsteps. The reason being that migrants, particularly refugees, have left everything they have in their countries of origin for safety and in search of a better life in a new homeland. Thus, if local communities act responsibly towards international migrants, they will bring a deep sense of peace to migrants who are always in fear of separation, discrimination, exploitation and abuse by the native people. Therefore, we have moved from Daniel Groody's image of God prism in migration theology to a constructive theology of the God's image in humankind that compels them to act responsibly towards each other, namely, dispositional ethics. This dispositional ethics arises from a thorough examination of Scripture regarding the meaning of the image of God in humankind.

\section{Acknowledgements Competing interests}

The authors declare that they have no financial or personal relationships which may have inappropriately influenced them in writing this article.

\section{Authors' contributions}

V.M. and C.M., equally contributed to the research and writing of this article.

\section{References}

Anderson, R.S., 2001, The shape of practical theology: Empowering ministry with theological praxis, Inter Varsity Press, Downers Grove.

Arnold, B.T., 2009, Genesis: The New Cambridge Bible Commentary, Cambridge Press, Cambridge.

Atkinson, D., 1990, The message of Genesis 1-11: The Bible speaks today, Inter-Varsity Press, Downers Grove, IL.

Aymer, M.P., 2015, 'Sojourners truths - The New Testament as diaspora space', The Journal of the Interdenominational Theological Centre 41, 1-18.

Barth, K., 1960a, Church dogmatics, III/1, edited by G.W. Bromiley \& T.F. Torrance, $\mathrm{T}$ and T Clark, Edinburgh.

Barth, K., 1960b, Church dogmatics, III/2, edited by G.W. Bromiley \& T.F. Torrance, $\mathrm{T}$ and T Clark, Edinburgh.

Bedford-Strohm, H., 2008, 'Responding to the challenges of migration and flight from a perspective of theological ethics', in Theological reflections on migration, a
churches Commission for Migrants in Europe Reader, Brussels, viewed 20 May 2016, from http://www.ccme.be/fileadmin/filer/ccme/01_WHO_WE_ARE/2008 CCME_Reader-_Theological_Reflections_on_Migration.pdf

Berkouwer, G.C., 1962, Studies in dogmatics: Man: The image of God, Eerdmans, Grand Rapids, MI.

Botha, N.A., 2013, 'A theological perspective on migrants and migration focussing on the Southern African Development Community (SADC)', Missionalia 41(2), 104-119. https://doi.org/10.7832/41-2-8

Cahalan, K.A. \& Mikoski, G.S. (eds.), 2014, Opening the field of practical theology: An introduction, Rowan and Littlefield, New York.
Calvin, J., 1965, Genesis: The Geneva series of commentaries (The edition reprinted from the Calvin Translation Society of 1847 in 1965), The Banner of Truth Trust, London.

Campese, G., 2012, 'The irruption of migrants: Theology of migration in the 21st century', Theological Studies 73(1), 3-32. https://doi.org/10.1177/004056 3912 07300101

Clines, D.J.A., 1968, 'The image of God in man', Tyndale Bulletin 19, 53-104.

Clines, D.J.A., 1993, 'Image of God', In G.F. Hawthorne (ed.), Dictionary of Paul and his letters: A compendium of contemporary biblical scholarship, pp. 426-428, Downers Grove, Illinois.

Coppedge, A., 1980, 'Holiness and discipleship', Wesleyan Theological Journal 15(2), 80-97.

De La Torre, M.A., 2011, Genesis: A theological commentary on the Bible, Westminster John Knox Press, Louisville, KY

Dillman, A., 1897, Genesis: Critically and exegetically expounded, T. and T. Clark, Edinburgh.

Dingemans, G.D.J., 1996, 'Practical theology in the academy + meeting the Modern University standards through 4 principle issues (discipline, status, methodology,
normative background) in religious tradition studies - A contemporary overview', normative background) in religio
Journal of Religion, 76(1), 82-96.

Fowler, J. W., 1983, 'Practical theology and the shaping of Christian lives', In D.S. Browning (ed.), Pastoral theology: The emerging field in theology, church and Browning (ed.), Pastoral theology: The emerging field
world, pp. 148-166, Harper and Row, San Francisco.

Gilmore, K., 2016, "Keynote address: Side event "Migrants in transit" by Deputy High Commissioner for Human Rights', viewed 20 May 2016, from http://www.ohchr.org

Groody, D.G., 2005, 'Undocumented migration and religious experience: A theological interpretation of the Mexican-American border', in L. Boeve, H. Geybels \& S.L. Van den Bosche (eds.), Encountering transcendence: Contributions to a theology of Christian religious experience, Peeters, Dudley, MA, pp. 359-374.

Groody, D.G., 2008, 'On the human face of the migrant', Missio Apostolica 16(1), 67-69.

Groody, D.G., 2009a, 'Crossing the divide: Foundations of a theology of migration and refugees', Theological Studies 70(3), 638-667. https://doi.org/10.1177/0040563 refugees', The
90907000306

Groody, D.G., 2009b, 'Jesus and the undocumented immigrant: A spiritual geography of a crucified people', Theological Studies 70(2), 298-316. https://doi.org/ $10.1177 / 004056390907000204$

Groody, D.G., 2009c, 'Crossing the divide: Foundations of a theology of migration and refugees', Theological Studies 70, viewed 28 March 2016, from http://ncronline. org/news/global/theology

Groody, D.G., 2010, Crossing the divide: Foundations of a theology of migration and refugees, Church Mission Society, Oxford.

Groody, D.G., 2012, 'Homeward bound: A theology of migration for fullness of life, justice and peace', The Ecumenical Review 64(3), 299-313. https://doi.org/ 10.1111/j.1758-6623.2012.00175.x

Groody, D.G., 2013, 'The Church on the move: Mission in age of migration', Mission Studies 30(1), 27-42. https://doi.org/10.1163/15733831-12341256

Groody, D.G., 2015, 'Passing over: Migration as conversion', International Review of Mission 104(400), 46-60. https://doi.org/10.1111/irom.12075

Hart, I., 1995, 'Genesis 1:1-2:3 as a prologue to the Book of Genesis', Tyndale Bulletin $46(2), 315-336$.

Hendriks, J., 2004, Studying Congregations in Africa, Lux Verbi, Wellington.

Hilkert, M.C., 1995, 'Cry beloved image: Rethinking the image of God', in A.O. Graff (ed.), The embrace of God: Feminist approaches to theological anthropology, pp. 190-204, Orbis, Maryknoll, NY.

Hendriks, J.H., 2007, 'Missional theology and social development', HTS 63(3), 999-1016.

International Organization for Migration (IOM), 2014, 'Global migration trends: An overview', viewed 28 May 2016, from http://missingmigrants.iom.int/sites/ default/files/documents/Global_Migration_Trends_PDF_FinalVH_with $\% 20$ References.pdf

Jackson, D. \& Passarelli, A., 2016, Mapping migration, mapping churches' responses in Europe: Belonging, community and integration: The witness and service of Europe: Belonging, community and integration: The Witness and service of www.ccme.be/.../2016-01-08-Mapping_Migration_2015_Online_lo-res_2_.pd

Keil, C.F. \& Delitzsch, F., 1987, 'Commentary on the old Testament in ten volumes', vol. 1 in The Pentateuch: Three volumes in one, Eerdmans, Grand Rapids, MI.

Kidner, D., 1967, Genesis: Tyndale Old Testament commentaries, Inter-Varsity Press, Downers Grove, IL.

Louw, D.J. 1998, A pastoral hermeneutics of care and encounter, Lux Verbi, Cape Town.

Louw, D.J., 2014, 'Wholeness in hope care on nurturing the beauty of the Human soul in spiritual healing', LIT, Wien.

Louw, D.J., 2015, 'On facing the God-question in a pastoral theology of compassion: From imperialistic omni-categories to theopaschitic pathos-categories', In die Skriflig 49(1), Art. \#1996, 1-15. https://doi.org/10.4102/ ids.v49i1.1996

Louw, D.J., 2016, 'Between xenophobia and xenodochia in an operative ecclesiology of home: The plight of refugees and migrants as challenge to a diagnostic approach in a pastoral hermeneutics of caregiving', Unpublished.

Magezi, C., 2017, 'Migration crisis and the church: A response to lacunae and considerations for Christian ministry engagement', Verbum et Ecclesia 38(1), a1671. https://doi.org/10.4102/ve.v38i1.1671

Magezi, M. \& Magezi, C., 2016, 'Pastoral care and healing in Africa: Towards an Adamic Christological practical theology imagination for pastoral healing', HTS Teologiese Studies/Theological Studies 72(2), a3467. https://doi.org/10.4102/hts.v72i2.3467 
Magezi, V., 2016, 'Pastoral care within globalisation care at the in-between: The dynamics of pastoral care and counselling for meaning and Coping in a global context', in U. Elsdörfer \& T.K. Ito (eds.), Compassion for one another in the Global Village: Social and cultural approaches to

Martin, P., 2013, 'The global challenge of managing migration', Population Bulletin 68(2), 1-15, viewed 23 April 2016, from www.prb.org/pdf13/global-migration.pdf

Middleton, R.J., 1994, 'The liberating image? Interpreting the imago Dei in context', Christian Scholars Review 24(1), 8-25.

Moltmann, J., 1991, God in creation, HarperCollins Pub, San Francisco, CA.

Ng'ang'a, S.W., 2010, 'Aspects of migrants theology of God and of human beings: A missiological exploration of some responses to the xenophobic violence in and around Tshwane', MA thesis, University of South Africa, Pretoria, May 2008.

Olsen, M., 2015, A reflection on Fr. Dan Groody's theology of migration, viewed 05 September 2017, from archstl.org/node/4358278.

Osmer. R., 2008, 'Practical theology: An introduction', WB Eerdmans, Grand Rapids, MI.

Polak, R., 2014, 'Migration als Ort der Theologie,' In T. Kessler (ed.), Migration als Ort der Theologie, Verlag Friedrich Pustet, Regensburg, pp. 1-20.
Rivera-Pagán, L.N., 2012, 'Xenophilia or xenophobia: Towards a theology of migration', The Ecumenical Review 64(4), 575-589. https://doi.org/10.1111/erev.12013

Simango, D., 2016, 'The Imago Dei (Gen 1:26-27): A history of interpretation from Philo to the present', Studia Historiae Ecclesiasticae 42(1), 172-190.

Skeldon, R., 2013, Global migration: Demographic aspects and its relevance for development, Technical paper, No. 2013/6, United Nations Department of Economic and Social Affairs, viewed 27 March 2016, from www.un.org/esa/ population/migration/documents/EGM.Skeldon_17.12.2013.pdf.

Skinner, J., 1930, A critical and exegetical commentary on Genesis, International Critical Commentary, T and T Clark, Edinburgh.

Torrance, T.F., 1996, 'The Christian doctrine of God: One being three persons', T \& T Clark, Edinburgh, NY.

United Nations Human Rights (UNHR), 2015, Migration, human rights and governance. Hand Book for parliamentarians no 24. 2015, Published by Inter-Parliamentary
Union 2015, viewed 2 April 2016, from www.ipu.org/PDF/publications/migrationen.pdf

Westermann, C., 1987, Genesis 1-11: A commentary, Augsburg, Minneapolis, MN.

Zetter, R., 1991, 'Labelling refugees: The forming and transforming of a bureaucratic identity', Journal of Refugee Studies 4, 39-62. https://doi.org/10.1093/ jrs/4.1.39 